\title{
Penggunaan Aplikasi Sound Level Meter Berbasis Android pada Pengukuran Kebisingan PLTD Ni'u Bima dan SDN 77 Kota Bima
}

\author{
Muhammad Subhan $^{1}$, Fatimah $^{2}$, Lis Suswati ${ }^{3}$ \\ ${ }^{1,2,3)}$ Program Studi Pendidikan Fisika STKIP-Bima. \\ Jl. Piere Tendean Kel. Mande Tel. Fax (0374) 42801, Bima 84191, Indonesia. \\ 1email : d.hans2102@gmail.com \\ 2 email : fathmariama@gmail.com \\ 3 email : finayuli123@gmail.com
}

\begin{abstract}
ABSTRAK : Lingkungan pendidikan seyogyanya mendukung terwujudnya suasana belajar dan proses pembelajaran, dimana peserta didik secara aktif dapat mengembangkan potensi diri sehingga memiliki kecerdasan intelektual, spiritual, akhlak serta keterampilan. Namun dalam kenyataaannya, perkembangan kebutuhan masyarakat menimbulkan masalah baru seperti berdampingannya SDN 77 Kota Bima dengan PLTD Ni'u Bima dalam penelitian ini. Sesuai aturan Menteri Lingkungan Hidup No. 48 Tahun 1996, intensitas standar lingkungan pendidikan $\leq 55 \mathrm{dBA}$. Otomatis intensitas diatas standar ini menjadi polutan dan harus dicari solusinya jika tidak, dapat mengganggu kesehatan apalagi jika terpapar dalam waktu yang lama. Penelitian ini merupakan pendekatan kuantitatif yang dimulai dengan tahapan pendahuluan, tahapan pengukuran data intensitas dan frekuensi, dan tahapan penyusunan rekomendasi penciptaan lingkungan belajar yang kondusif dalam bentuk bahan ajar mahasiswa yang berisi konsep dan aplikasi rekomendasi sekolah berbasis kebisingan. Teknik pengukuran terdiri dari 2 yaitu jarak dari sumber bising dan keliling pada PLTD serta lingkungan sekolah. Adapun data hasil pengukuran rata - rata di dalam PLTD memiliki $\left(\mathrm{L}_{\max }\right) 100 \mathrm{dBA}$, $\left(\mathrm{L}_{\min }\right)$ 85,64 dBA, ( $\left.\mathrm{L}_{\text {avg }}\right)$ 88,46 dBA dengan frekuensi $1.250 \mathrm{~Hz}$ dan 2 klasifikasi Subway Train serta Factory machinery. Sedangkan pada lingkungan sekolah $\left(\mathrm{L}_{\max }\right)$ 86,0 dBA, ( $\left.\mathrm{L}_{\min }\right)$ 71,0 dBA, ( $\left.\mathrm{L}_{\text {avg }}\right)$ 79,59 dBA dengan frekuensi $950 \mathrm{~Hz}$ dan klasifikasi Busy street serta Busy traffic. Keseluruhan tahapan penelitian memberikan indikasi kuat akan perlunya upaya treatment lingkungan sekolah demi terjaganya konduktivitas lingkungan belajar
\end{abstract}

Kata kunci: Kebisingan, Lingkungan, Belajar, Kondusif,

\section{PENDAHULUAN DAN KAJIAN LITERATUR}

Di era digital saat ini sangat memungkinkan kemudahan untuk memperoleh media sebagai sarana yang dapat membantu suatu pekerjaan. Perkembangan teknologi, informatika dan komputer bersanding seiring maju dengan dunia pendidikan sehingga dapat membantu untuk menyelesaikan pekerjaan dalam berbagai bidang tidak terkecuali dalam pembelajaran terkhusus bidang fisika. Pembelajaran fisika tidak lepas dari kegiatan praktikum, yang dimana salah satu kegiatan yang sering dilakukan dalam kegiatan praktikum adalah mengukur. Kegiatan mengukur dalam melakukan eksperimen untuk membuktikan suatu teori ataupun untuk memperoleh data pelengkap suatu besaran fisis tentu memerlukan alat ukur.

Di dalam penelitian ini dibutuhkan alat ukur untuk melihat tingkat intensitas kebisingan yaitu dengan menggunakan Sound Level Meter. Sound Level Meter tidak hanya tersedia dalam bentuk perangkat keras namun juga sudah terdapat yang berbasis android sudah tersedia dalam playstore dan dapat didownload secara gratis dan terdapat juga berbayar. Aplikasi sound level meter ini sangat membantu dan dapat dimanfaatkan untuk kebutuhan pembelajaran dalam pengukuran intensitas kebisingan disuatu lingkungan termasuk lingkungan pendidikan.

Terbentuknya lingkungan pendidikan yang mendukung seluruh aktifitas belajar mengajar secara kondusif menjadi titik tekan tujuan pendidikan, terlebih dalam usaha mewujudkan suasana belajar dan proses pembelajaran agar peserta didik secara aktif mengembangkan potensi diri serta kecerdasannya. Menurut Mulyasa (2009) lingkungan pembelajaran yang kondusif harus memenuhi tujuh elemen yaitu (1) Ruang belajar, (2) Pengaturan sarana belajar, (3) Susunan tempat duduk, (4) Penerangan, (5) Suhu, (6) Apersepsi sebagai pembentukan dan pengembangan kompetensi, dan (7) Bina suasana dalam pembelajaran. Secara ideal lingkungan pembelajaran yang kondusif dalam arti mendukung semua kegiatan pendidikan 
haruslah mampu mensinergikan elemen - elemen ini, dimana lingkungan belajar sebagai faktor prioritas untuk dirancang penuh kenyamanan oleh pihak sekolah.

Lingkungan sekolah yang bising serta tidak nyaman menjadi konsekwensi yang harus diterima karena semakin kompleksnya kebutuhan masyarakat yang sejalan dengan penambahan jumlah keluarga. Salah satu dampaknya yaitu lingkungan sekolah yang berdampingan langsung dengan aktivitas masyarakat dan membawa serta bising dilingkungan sekitar. Disisi lain, lingkungan sekolah harus memenuhi intensitas bising yang ditetapkan WHO (World Health Organization) dan Baku Tingkat Kebisingan yang ditetapkan Menteri Lingkungan Hidup (MENLH) sesuai Keputusan No. 48 Tahun 1996 yaitu tidak lebih dari $55 \mathrm{dBA}$ (Acet, 2005).

Berbicara mengenai layanan pendidikan, Kota Bima sebagai salah kota otonom di pulau Sumbawa sesuai UU No. 13 tahun 2002 mengalami peningkatan jumlah penduduk yang mau tidak mau harus diikuti oleh peningkatan fasilitas sekolah yang memadai. Seyogyanya akses pendidikan bagi masyarakat harus menjangkau tempat masyarakat berdomisili/berada dekat dengan lokasi tempat tinggal masyarakat. Dilingkungan kelurahan Dara lebih tepatnya desa Ni'u terdapat SDN 77 Kota Bima yang menjangkau tempat tinggal masyarakat namun disisi lain ikut berdampingan dengan layanan supply listik untuk kebutuhan masyarakat yaitu Pembangkit Listrik Tenaga Diesel (PLTD) yang menyupply kebutuhan listik daerah Kota Bima, Kabupaten Bima sampai Dompu. Berdasarkan survey awal, keberadaan PLTD terhitung sejak tahun 1998 sedangkan keberadaan SDN 77 Kota Bima sekitar tahun 2005. Keberadaan PLTD yang lebih dulu dibandingkan SD melatarbelakangi penelitian sejauhmana standar kebisingan yang keluar dari aktifitas PLTD mempengaruhi aktifitas belajar mengajar. Berdasarkan survey awal pula, menggunakan aplikasi software Sound Level Meter (SLM) diperoleh nilai intensitas kebisingan di SD yaitu berada dikisaran 79-84 dB dengan kategori bising lalu lintas jalan yang ramai dan sibuk. Sedangkan standar yang diperbolehkan sebesar $55 \mathrm{~dB}$ sebagaimana sudah diuraikan sebelumnya. Dari fakta dilapangan ini, maka melalui penelitian ini memerlukan ekplorasi terhadap berapa intensitas dan frekuensi di lingkungan sekolah ? mengeksplorasi lebih jauh adakah hubungan antara kebisingan dengan aktivitas belajar mengajar? dan rekomendasi apa yang dapat diberikan kepada pihak PLTD agar ikut serta menciptakan lingkungan belajar yang kondusif yang dibuat dalam bentuk bahan ajar mahasiswa.
Menurut Gabriel kebisingan adalah bunyi yang tidak dikehendaki yang merupakan aktivitas alam (bunyi yang mengganggu pendengaran), bunyi yang berasal dari buatan manusia (bunyi karena aktivitas yang berhubungan dengan pekerjaan dan mesin), serta bunyi impulsif/menyentak yang dapat berakibat pada kenyamanan dan kesehatan. Definisi lain diuraikan Purnanta (2008) Bising sebagai bunyi tidak dikehendaki yang merupakan aktivitas alam atau buatan manusia. Tingkat kebisingan/noise level merupakan fungsi amplitudo gelombang suara yang dinyatakan dalam decibel. Ada tiga cara berbeda yang sering digunakan untuk mendefinisikan tingkat kebisingan yaitu (1) Sound intensity level (SIL) sebagai perhitungan nilai logaritma dari perbandingan antara intenisitas suara, (2) Sound power level (PWL) sebagai nilai logaritma perbandingan daya suara, dan (3) Sound pressure level (SPL) sebagai nilai logaritma perbandingan tekanan suara (Tambunan, 2005). Level kebisingan merupakan fungsi dari amplitudo gelombang suara dan dinyatakan dalam satuan decibel $(\mathrm{dB})$, dimana skala dBA untuk menilai tanggapan manusia terhadap level bising lingkungan luar dan dalam bangunan, seperti bising lalu lintas, bising ruangan kantor yang direkomendasikan oleh ISO (International Organization of Standardization) dan dianggap paling sesuai dengan tanggapan manusia terhadap suara (bising). Bising yang mengganggu pendengaran, tidak hanya bergantung pada level intensitas kebisingan, melainkan juga pada lama kebisingan yang berlangsung, sehingga didefinisikan SIL sebagai fungsi waktu yaitu level intensitas kebisingan ekivalen (equivelent continus noise level). Konsep nilai level intensitas kebisingan ekivalen dari kebisingan yang berubah - ubah (fluktuatif) selama selang waktu tertentu yang setara dengan tingkat kebisingan yang tetap (steady) pada selang waktu yang sama asalkan energi totalnya sama (Wilson, 1989).

Penggunaan alat untuk mengukur intensitas kebisingan adalah Sound Level Meter (SLM) berbasis android yang terinstal dalam computer Lenovo 10-30 karena dibutuhkan perangkat tambahan yaitu soundcard computer dengan kalibrator GM 1352 merk Benetech. Sedangkan pengukuran frekuensi menggunakan aplikasi frekuensi berbasis sound card model aplikasi Advance Spectrum Analyzer Pro Freqency, dimana alat ini secara real time mampu menvisualisasikan dan menganalisa sinyal yang kuat dari mikrofon perangkat android dalam domain frekuensi. Pengambilan data penelitian dilakukan saat kegiatan belajar mengajar dan saat mesin PLTD beroperasi bersamaan, yaitu antara jam 07.00 sampai jam 13.00 wita. 
Salah satu rekomendasi dengan bising lingkungan lingkungan sekolah melalui pertimbangan material akustik yang dipakai untuk menciptakan kenyamanan ruangan. Menurut Tambunan (2005), selain kemampuan menyerap/meredam suara, faktor-faktor lain yang sebaiknya menjadi pertimbangan yaitu ketebalan material, ketahanan api, kemudahan pemasangan, kemudahan Perawatan, dan keindahan. Selain itu, ada 3 konsep yang harus diperhatikan akan pengembangan sistem akustik sebuah bangunan, yaitu Akustik dalam ruangan (interior akustik), insulasi suara (sound insulation) dan Kebisingan (noise). Secara teknis, ketiga konsep utama yang telah diterapkan pada beberapa teknik engineering control seperti :penghalang kebisingan (sound barrier), penyerap kebisingan (noise absorber) dan peredam kebisingan (noise damper).

\section{METODE PENELITIAN}

Jenis penelitian ini adalah gabungan antara penelitian kuantitatif dan kualitatif, guna mengindentifikasi nilai kebisingan dilingkungan PLTD dan lingkungan sekolah melalui pengukuran data intensitas dan frekuensi. Untuk mendapatkan solusi berupa rekomendasi lingkungan belajar yang kondusif dapat ditunjang dengan pendekatan kuantitatif lewat pengukuran reduksi bising melalui perbandingan secara langsung kondisi bising standar untuk lingkungan pendidikan yaitu $\leq 55 \mathrm{~dB}$ dengan bising hasil pengukuran serta ditunjang dengan teori pendukung lain guna mengoptimalkan lingkungan belajar di SDN 77 Kota Bima. Adapun tahapan penelitian yaitu pendahuluan, pengukuran intenistas dan frekuensi, Pada tahap akhir perumusan rekomendasi penciptaan lingkungan belajar yang kondusif dalam bentuk bahan ajar mahasiswa yang diharapkan menjadi referensi.

\section{HASIL DAN PEMBAHASAN}

Secara umum sumber bising di lokasi PLTD dibagi menjadi 2 yaitu sumber bising yang berasal dari 2 unit mesin diesel milik PLN dan mesin milik swasta (Sewatama). Adapun mesin milik PLN berada dalam ruangan tertutup, sedangkan mesin swasta dalam keadaan terbuka hanya dibatasi dengan seng baja ringan dalam posisi terbuka. Jika ditarik garis lurus, lokasi mesin swasta menjadi penyumbang bising kearah utara arah sekolah SDN 77 Kota Bima (walaupun juga merupakan hasil akumulasi intensitas dengan mesin milik PLN karna jaraknya yang saling berdekatan). Total titik pengukuran dengan teknik jarak dari sumber bising di area PLTD sebanyak 25 titik. Sedangkan titik pengukuran dengan teknik keliling sumber bising diambil 29 titik sampel pengukuran. Untuk titik pengukuran di lingkungan sekolah menggunakan teknik pengukuran acak keliling lingkungan sekolah dengan 68 titik sampel dan teknik pengukuran pada salah satu ruangan yang dianggap paling banyak menerima dampak dari aktivitas bising PLTD serta bising dari aktivitas belajar mengajar sekolah sendiri (kelas sampel bising) yaitu sebanyak 23 titik sampel.

Tabel 1 Tabel Hasil Pengukuran Intensitas dan

Frekuensi Dengan Teknik Jarak Dari Sumber Bising PLTD

Hari/Tanggal Pengukuran : Jum'at/2 Maret 2018 (Hari $\mathrm{ke}-1)$

\begin{tabular}{|c|c|c|c|c|c|c|c|}
\hline \multirow[b]{2}{*}{$\begin{array}{c}\text { Deskripsi } \\
\text { Sumber Bunyi }\end{array}$} & \multirow[b]{2}{*}{$\begin{array}{l}\text { Letak Titik } \\
\text { Pengukuran }\end{array}$} & \multirow[b]{2}{*}{ Keterangan } & \multicolumn{3}{|c|}{ Data Intensitas (dB) } & \multirow[b]{2}{*}{$\begin{array}{r}\text { Frek } \\
(\mathrm{Hz})\end{array}$} & \multirow[b]{2}{*}{$\begin{array}{l}\text { Klsfks } \\
\text { Bising }\end{array}$} \\
\hline & & & $\stackrel{\mathrm{L}}{\mathrm{min}}$ & $\begin{array}{c}\mathrm{L} \\
\text { Max }\end{array}$ & $\begin{array}{c}\mathrm{L} \\
\text { avg }\end{array}$ & & \\
\hline $\begin{array}{l}\text { Lokasi } 1 \text { : } \\
\text { Area Sumber } \\
\text { Mesin } 2 \text { Unit } \\
\text { (sumber } \\
\text { bising utama) }\end{array}$ & $\begin{array}{l}\text { Di dalam } \\
\text { area } 2 \text { unit } \\
\text { mesin yang } \\
\text { sedang } \\
\text { beroperasi } \\
\text { secara } \\
\text { bersamaan } \\
\text { (Posisi } \\
\text { tengah } \\
\text { diantara } 2 \\
\text { mesin MAK) }\end{array}$ & $\begin{array}{c}\text { Spesifikasi } \\
\text { Mesin : Merk } \\
\text { mesin MAK, } \\
\text { Tipe } 8 \text { M 453 C, } \\
\text { No Seri } 2724 \text { \& } \\
287275, \text { Daya } \\
\text { Terpasang } \\
2940 \text { KW, } \\
\text { Putaran mesin } \\
600 \text { RPM, } \\
\text { Tahun } \\
\text { Pembuatan } \\
\text { 1998, Tahun } \\
\text { operasi } 1999 \\
\end{array}$ & 98 & 100 & 100 & 1250 & $\begin{array}{c}\text { Subway } \\
\text { train }\end{array}$ \\
\hline $\begin{array}{l}\text { Lokasi } 5: \mathrm{Di} \\
\text { luar ruangan } \\
\text { sumber mesin } \\
\quad 2 \text { Unit }\end{array}$ & $\begin{array}{c}\text { Di luar } \\
\text { ruangan } \\
\text { area } 2 \text { unit } \\
\text { mesin yang } \\
\text { sedang } \\
\text { beroperasi } \\
\text { secara } \\
\text { bersamaan }\end{array}$ & $\begin{array}{l}\text { Posisi } 5 \text { meter } \\
\text { dari ruangan }\end{array}$ & 92 & 96 & 93 & 800 & $\begin{array}{c}\text { Factory } \\
\text { Machin } \\
\text { ery }\end{array}$ \\
\hline $\begin{array}{c}\text { Lokasi 11: } \\
\text { Selasar Kelas } \\
1\end{array}$ & $\begin{array}{l}\text { Jarak } 140 \\
\text { meter }\end{array}$ & $\begin{array}{l}\text { Selasar kelas } \\
\text { (kelas kosong, } \\
\text { setelah KBM) }\end{array}$ & 67 & 74 & 70 & 700 & $\begin{array}{l}\text { Busy } \\
\text { Trafic }\end{array}$ \\
\hline
\end{tabular}

Adapun hasil pengukuran dengan 3 teknik lainnya digambarkan pada grafik hubungan antara intensitas, frekuensi dan klasifikasi bising.

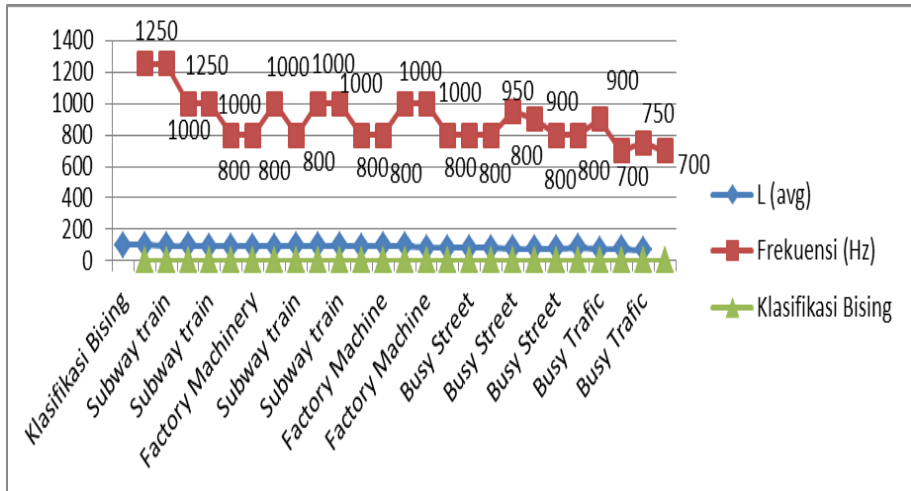

Grafik 1. Pengukuran Teknik Jarak Dari Sumber Bising Di Dalam Area PLTD

Pada grafik 1 dapat dilihat klasifikasi bising tertinggi Subway Train berada pada nilai rata - rata intensitas $\left(\mathrm{L}_{\text {avg }}\right) 100 \mathrm{dBA}$ dan pada frekuensi tertinggi $1.250 \mathrm{~Hz}$. Sedangkan klasifikasi terendah Busy Trafic berada pada rata - rata intensitas $70 \mathrm{dBA}$ dengan frekuensi $700 \mathrm{~Hz}$. Secara umum, grafik memperlihatkan 4 klasifikasi yaitu 
Subway train (setara mesin kereta api yang sedang beroperasi), Factory machinery (setara mesin pabrik), Busy street (setara jalan yang sibuk) dan Busy trafic (setara lalu lintas yang sibuk). Dapat dilihat pada grafik 3.2, klasifikasi bising tertinggi Factory machinery berada pada nilai rata - rata intensitas $\left(\mathrm{L}_{\text {avg }}\right) 94 \mathrm{dBA}$ dan pada frekuensi tertinggi $10.000 \mathrm{~Hz}$. Sedangkan klasifikasi terendah Busy street berada pada rata - rata intensitas 85 dBA dengan frekuensi $800 \mathrm{~Hz}$. Secara umum, grafik memperlihatkan 2 klasifikasi yaitu Factory machinery (setara mesin pabrik) dan Busy street (setara jalan yang sibuk).

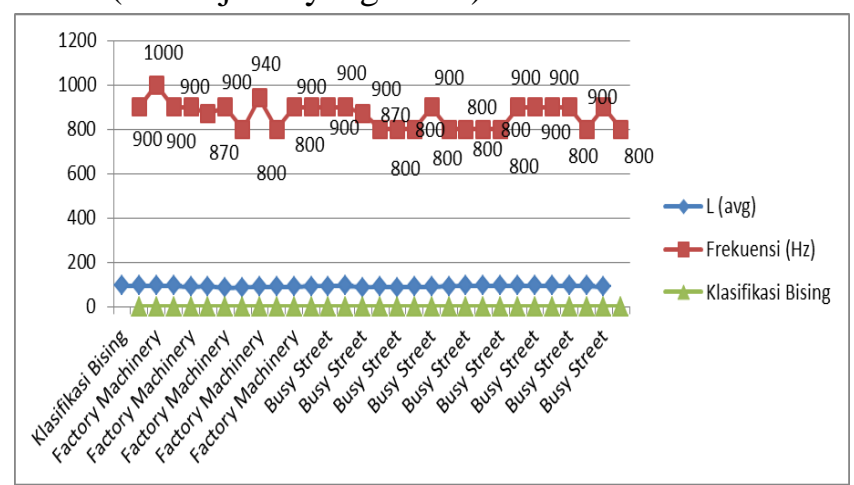

Grafik 2. Teknik Pengukuran Keliling Sumber Bising Area PLTD

Secara umum, dari hasil pengukuran jika mengacu pada aturan NIOSH (national institute of occupational safety and health) sumber bising tidak boleh lebih dari 104 dBA. Dalam arti intensitas pada sumber bising PLTD baik mesin diesel milik PLTD dan mesin milik swasta masih pada nilai $100 \mathrm{~dB}$ dalam arti masih pada rentan yang diperbolehkan. Pada kondisi ini sesuai aturan NIOSH dan umumnya aturan $K 3$ (kesehatan dan keselamatan kerja) direkomendasikan karyawan yang bekerja hanya boleh menghadapi tingkat kebisingan 85 dBA selama tidak lebih dari 8 jam, jika dilanggar dapat menyebabkan terjadinya occupational hazard (bahaya kerja) baik secara fisik berupa gangguan pada telinga maupun gangguan psikis (gangguan konsentrasi dan kelancaran komunikasi) yang sifatnya serius.

Dapat dilihat pada grafik 3.3, klasifikasi bising tertinggi Busy trafic berada pada nilai rata - rata intensitas $\left(\mathrm{L}_{\mathrm{avg}}\right)$ 86 dBA dan pada frekuensi tertinggi $950 \mathrm{~Hz}$. Sedangkan klasifikasi terendah Busy street berada pada rata - rata intensitas $71 \mathrm{dBA}$ dengan frekuensi $800 \mathrm{~Hz}$. Secara umum, grafik memperlihatkan 2 klasifikasi yaitu Busy trafic (setara lalu lintas yang sibuk) dan Busy street (setara jalan yang sibuk).

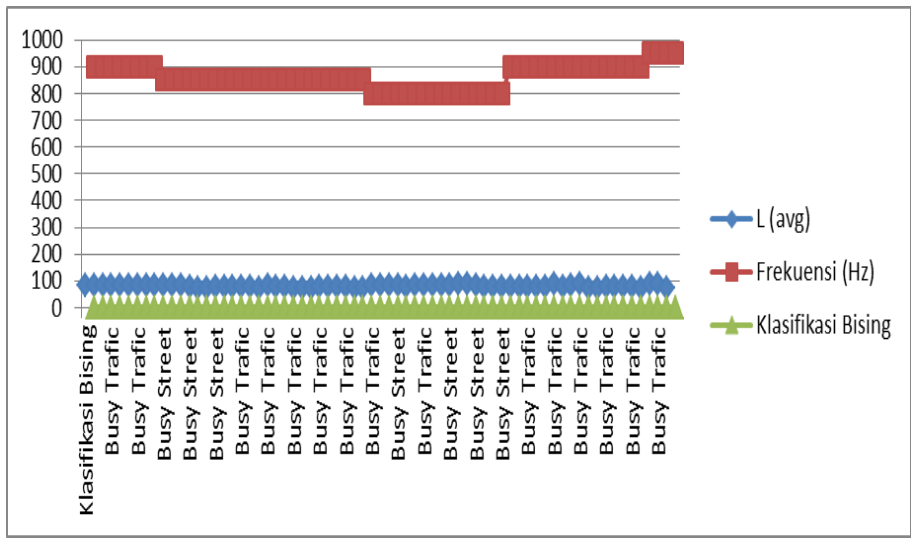

Grafik 3 Pengukuran Teknik Pengukuran Keliling Lingkungan Sekolah

Secara umum, dari hasil pengukuran di lingkungan sekolah dan di kelas sampel melebihi aturan yang ditetapkan berdasarkan Baku Mutu Tingkat Kebisingan yang diisyaratkan oleh KEP.48/MENLH/11/1996 yaitu 55 dBA untuk lingkungan sekolah. Dimana kisaran intensitas bising di SDN 77 Kota Bima rata - rata berada pada intensitas 81,62 dBA, sehingga dari hasil pengukuran ini menjadi fokus kami untuk melakukan treatment terhadap ruangan yang sampel kelas bising dengan target mampu mereduksi bising dengan NR (noise reduction) antara 15 - 20 sebagai standar NR ruangan sekolah (Tambunan, 2005).

Sedangkan penyusunan bahan ajar dimaksudkan untuk membantu mahasiswa memahami konsep, aplikasi serta rekomendasi dari penelitian ini. Sistematika isi bahan ajar meliputi : Konsep Lingkungan Belajar Yang Kondusif, Sistem Pendengaran Manusia, Kebisingan di Lingkungan Sekolah, Sistem Akustik, Pengendalian Kebisingan, dan Aplikasi Konsep Akustik dan Rekomendasi Dalam Pendidikan.

\section{KESIMPULAN}

Berdasarkan hasil penelitian, maka dapat diambil kesimpulan sebagai berikut:

1. Teknik pengukuran dalam penelitian terdiri dari 2 yaitu jarak dari sumber bising dan keliling yang diaplikasikan pada area PLTD serta lingkungan sekolah dengan masing - masing 3 hari pengukuran. Adapun area PLTD memiliki rata - rata $\mathrm{L}_{\max } 96,24$ $\mathrm{dBA}, \mathrm{L}_{\min } 86,59 \mathrm{dBA}$ dan $\mathrm{L}_{\text {avg }} 89,76 \mathrm{dBA}$ dengan frekuensi antara $1.250-1.000 \mathrm{~Hz}$ dan klasifikasi Subway Train (setara mesin kereta api) serta Factory machinery (setara mesin pabrik). Sedangkan pada lingkungan sekolah rata - rata memiliki $\mathrm{L}_{\max } 87$ $\mathrm{dBA}, \mathrm{L}_{\min }$ 67,50 dBA, $\mathrm{L}_{\text {avg }}$ 81,62 dBA dengan frekuensi $950 \mathrm{~Hz}$ dan klasifikasi Busy street (setara jalanan yang sibuk) serta Busy traffic (setara lalu 
lintas yang sibuk). Nilai intensitas area PLTD menurut NIOSH (national institute of occupational safety and health) tidak boleh lebih dari $104 \mathrm{dBA}$ yang artinya masih pada rentan yang diperbolehkan, sedangkan lingkungan sekolah menggunakan aturan KEP.48/MENLH/11/1996 yaitu 55 dBA, maka harus direduksi bising di SDN 77 Kota Bima.

2. Dengan data non pengukuran hasil kuesioner digambarkan bahwa terdapat "Hubungan Yang Kuat" antara variabel kebisingan dengan variabel aktivitas belajar mengajar yang ditunjukkan dengan koefisien korelasi 0,747. Hal ini juga didukung oleh instrument hasil observasi, wawancara tertutup serta dokumentasi, sehingga perlu diupayakan treatment lingkungan sekolah demi terjaganya konduktivitas lingkungan belajar.

3. Adapun rekomendasi untuk menciptakan lingkungan belajar yang kondusif dibuat dalam bentuk bahan ajar yang berisi konsep dan aplikasi rekomendasi yang dapat menjadi panduan pada bising lingkungan sekolah (educational noise).

\section{REFERENSI}

[1] Acet. 2005. Pelatihan Noise Control Management Service Indonesia. Bandung. PT. Quadrant Utama

[2] Gabriel J. F, .1996. Fisika Kedokteran. Jakarta. Penerbit Buku Fisika Kedokteran ECG

[3] Lampiran Undang-Undang Tentang Sistem Pendidikan Nasional. Nomor 20 Tahun 2003

[4] Lampiran Surat Keputusan Menteri Lingkungan Hidup Tentang Baku Mutu Tingkat Kebisingan Nomor 48 November 1996

[5] Mulyasa, E. (2009). Implementasi Kurikulum 2004

Panduan Pembelajaran KBK. Jakarta. PT. Remaja Rosdakarya

[6] Salinan Pelunjuk Pelaksanaan Pengawasan Kebisingan Departemen Kesehatan RI (1995). Jakarta

[7] Tambunan, B. T. S. (2005). Occupational Noise. Yogyakarta. Andi

[8] Wilson, E. C. (1989). Noise Control. New York. Harper \& Row 